\title{
HIV-1 Nef increases astrocyte sensitivity towards exogenous hydrogen peroxide
}

\author{
Sabine Masanetz ${ }^{1}$, Michael H Lehmann ${ }^{1,2^{*}}$
}

\begin{abstract}
Background: HIV-1 infected individuals are under chronic exposure to reactive oxygen species (ROS) considered to be instrumental in the progression of AIDS and the development of HIV-1 associated dementia (HAD). Astrocytes support neuronal function and protect them against cytotoxic substances including ROS. The protein HIV-1 Nef, a progression factor in AIDS pathology is abundantly expressed in astrocytes in patients with HAD, and thus may influence its functions.
\end{abstract}

Results: Endogenous expressed HIV-1 Nef leads to increased sensitivity of human astrocytes towards exogenous hydrogen peroxide but not towards TNF-alpha. Cell death of nef-expressing astrocytes exposed to $10 \mu \mathrm{M}$ hydrogen peroxide for 30 min occurred within $4 \mathrm{~h}$.

Conclusion: HIV-1 Nef may contribute to neuronal dysfunction and the development of HAD by causing death of astrocytes through decreasing their tolerance for hydrogen peroxide.

\section{Background}

Both HIV-1 associated dementia (HAD) and a milder form of HIV-1 associated cognitive disorder, known as minor cognitive and motor disorder (MCMD) are frequent complications of the acquired immunodeficiency syndrome (AIDS) and are characterized by neuronal dysfunction and cell death caused by HIV-1 through direct and indirect mechanisms [1-4].

Recently, a sophisticated inspection of brains from HIV-1 infected patients confirmed that neurons are not infected with HIV-1 and surprisingly revealed that astrocytes, the most abundant cell type in the brain, are extensively infected. Additionally, this study elucidated that infection of astrocytes with HIV-1 correlated with the severity of neuropathology [5]. Astrocytes play an important role in maintaining homeostasis, providing neuroprotection and regulating physiological activities within the brain [6-8]. Therefore, astrogliosis and astrocyte death occurring in HIV-infected individuals [9-12] may contribute indirectly to neuronal dysfunction.

Even though HIV-1 is integrated in the astrocyte genome, it rarely replicates in this cell type in vivo, however,

\footnotetext{
* Correspondence: Orlataler@web.de

${ }^{2}$ Institute for Infectious Diseases and Zoonoses, Ludwig-Maximilians-

University Munich, 80539 Munich, Germany

Full list of author information is available at the end of the article
}

regulatory proteins such as Nef are found to be abundantly expressed [13-15]. The presence of HIV-1 Nef in the brain is associated with astrogliosis and recruitment of monocytes/macrophages [16], correlating with the development of HAD [17].

Astrocytes stably transfected with HIV-1 Nef function as appropriate cellular model systems for the purpose of investigating basic mechanisms pertinent to the understanding of HAD pathogenesis. Using these cells, we previously showed that HIV-1 Nef induces CCL2/MCP-1 [18], thereby, providing an alternative hypothesis for the occurrence of this chemokine at high concentrations in the cerebrospinal fluid (CSF) of HIV-infected individuals with HAD $[19,20]$. CCL2 plays an important role in the cerebral infiltration of monocytes/macrophages in these patients $[21,22]$. Infiltrated and activated monocytes/ macrophages, which are considered to be the effector cells in cellular and tissue damage in AIDS, produce cytotoxic substances such as reactive oxygen species (ROS) and inflammatory cytokines [23,24]. Consequently, HIV-1 infected and non-infected astrocytes are subjected to an environment characterized, amongst others, by high concentrations of hydrogen peroxide and tumor necrosis factor (TNF)-alpha. Therefore, the aim of this study was to investigate the effect of HIV-1 Nef on the 
cellular viability of human astrocytes exposed to these particular cytotoxic substances.

\section{Results}

Astrocytes stably transfected with HIV-1 nef are highly sensitive to hydrogen peroxide induced cell death Astrocytes fulfil a protective function for neurons through elimination of ROS such as hydrogen peroxide [25]. Yet astrocytes are more vulnerable to the effects of hydrogen peroxide than neurons [26,27], but it is not known how this is modulated by HIV-1 Nef. Therefore, the sensitivity of human astrocytic U251MG-Nef cells towards hydrogen peroxide was tested in comparison with the sensitivity of U251MG-parental and U251MG-pNeo cells. Cells treated with hydrogen peroxide at concentrations of $1 \mu \mathrm{M}$ and $10 \mu \mathrm{M}$ for $30 \mathrm{~min}$ were investigated after $24 \mathrm{~h}$ for viability using AlamarBlue ${ }^{\circledR}$ reagent containing resazurin, a non-toxic, oxidation-reduction indicator indicating mitochondrial metabolic activity. The analysis revealed that in astrocytic cells stably expressing nef, hydrogen peroxide significantly reduced the cell viability as compared to mock-treated cells, hydrogen peroxide-treated U251MGparental cells and hydrogen peroxide-treated U251MGpNeo cells (Figure 1). Similar results were obtained at $48 \mathrm{~h}$ (additional file 1).

\section{Hydrogen peroxide rapidly induced cell death of} astrocytes stably transfected with HIV-1 nef

A light microscopic analysis was performed in order to examine whether signs of cell death induced by hydrogen peroxide may be detected earlier than $24 \mathrm{~h}$ in nefexpressing astrocytes. Indeed, in contrast to the control cells, the previously flat-shaped nef-expressing astrocytes had undergone a morphological alteration to being round-shaped and almost completely detached from the cell culture flask surface $3 \mathrm{~h} 30 \mathrm{~min}$ subsequent to 30 min treatment with hydrogen peroxide at a concentration of $10 \mu \mathrm{M}$ (Figure 2).

Translocation of the membrane phospholipid phosphatidylserine (PS) to the outer leaflet of the plasma membrane occurs rapidly after exposure to a cytotoxic agent and mostly indicates a point-of-no-return during the cellular dying process. Using the Annexin V assay, it was confirmed that hydrogen peroxide at a concentration of $10 \mu \mathrm{M}$ severely affected cellular viability of U251MG-Nef cells but had only a small effect on astrocytic U251MG-parental and U251MG-pNeo cells. PS exposure on the cell surface in combination with positive PI staining indicating loss of plasma membrane integrity, which is criterion to consider a cell as dead [28], has been detected in about $75 \%$ of the nefexpressing cells (Figure 3).

\section{Astrocytes stably transfected with HIV-1 nef are as sensitive to TNF-alpha induced cell death as non- transfected cells}

Previously, it has been shown that HIV-1 Nef protects $\mathrm{T}$ cells against TNF-alpha induced apoptosis [29]. Consequently, we tested whether HIV-1 Nef is also capable of protecting astrocytes against TNF-alpha induced cell death. Human astrocytic U251MG-parental, -pNeo and -Nef cells were treated with TNF-alpha for $24 \mathrm{~h}$ and their viability was analysed using AlamarBlue ${ }^{\circledR}$ reagent. Data revealed that TNF-alpha significantly reduced the cell viability of each astrocytic cell type investigated here to a similar degree including the stably $n e f$-transfected

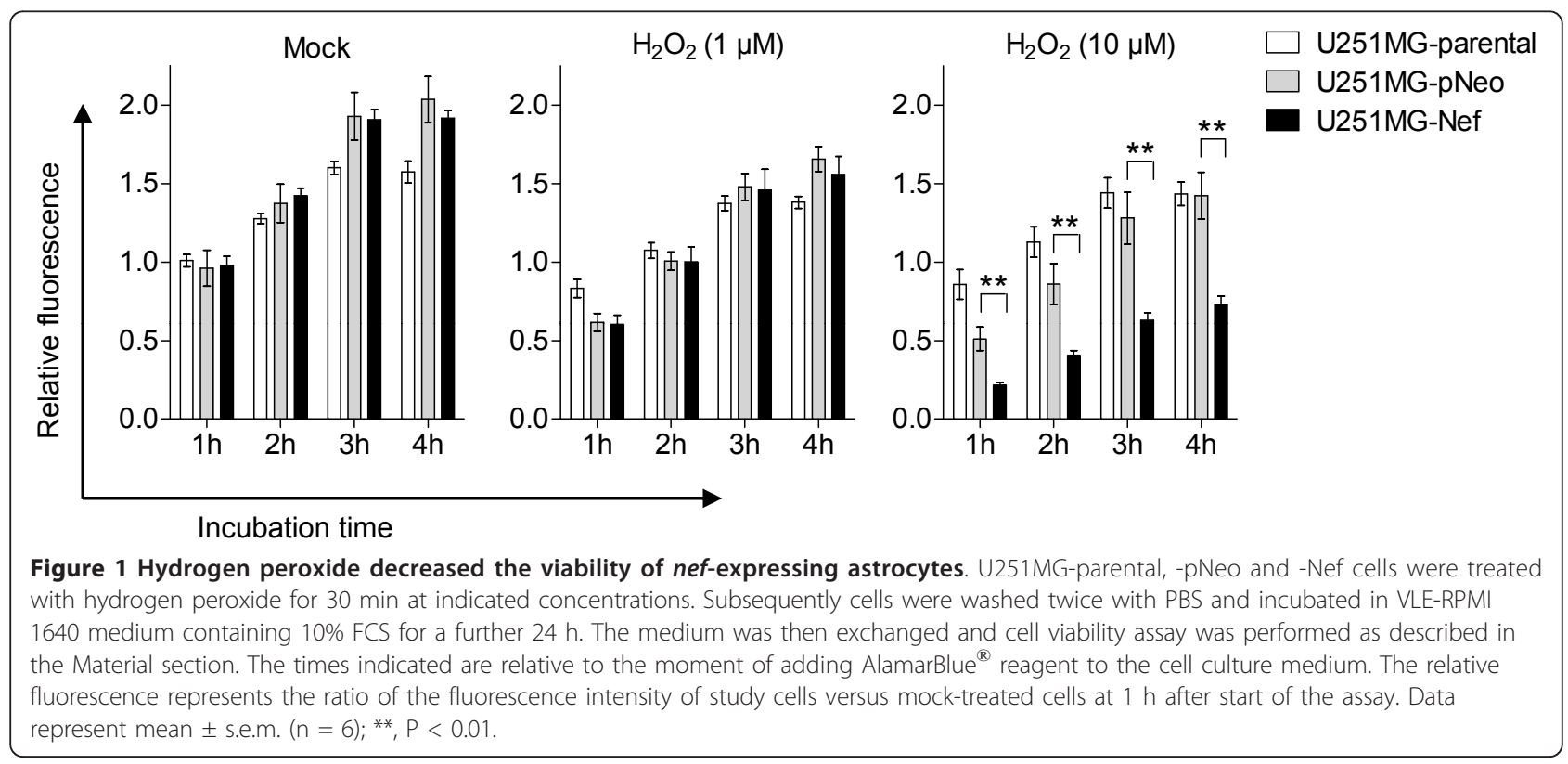




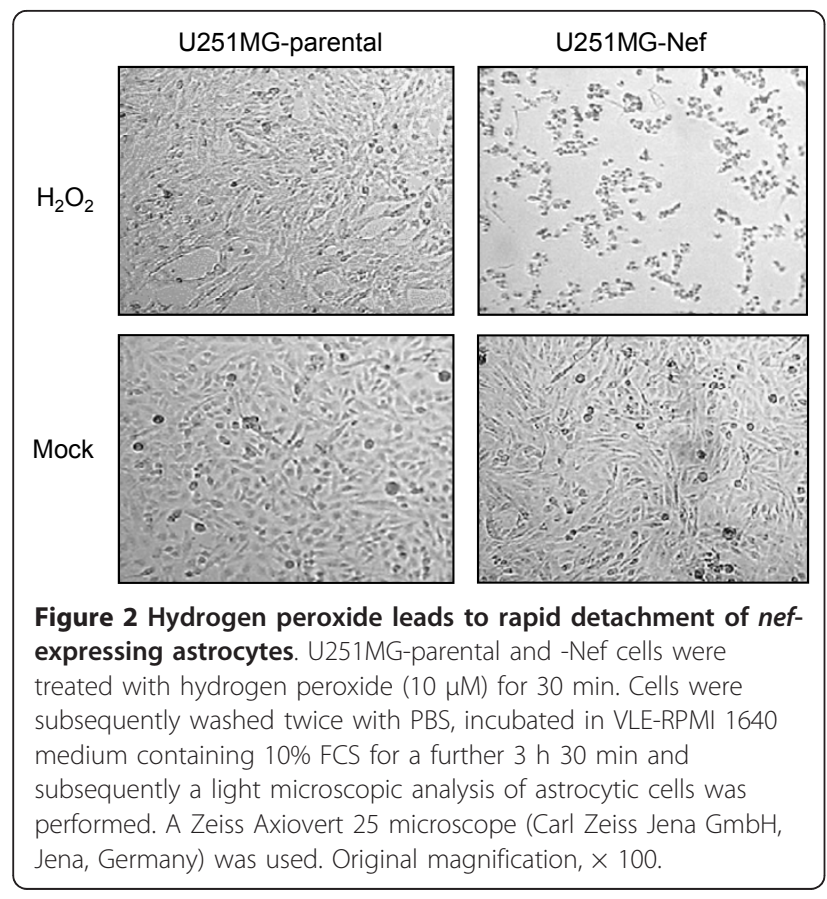

cells (Figure 4). This result has been confirmed using the Annexin V assay (additional file 2).

\section{Discussion}

Chronic oxidative stress in HIV-infected patients plays an important role in AIDS progression [30,31]. This phenomenon is explained by a depletion of endogenous antioxidant moieties and an increased production of ROS. Oxidative stress, in particular, is thought to be a cause of neuronal cell death in the brain of HIV-1 infected patients and believed to contribute to development of HAD [32,33]. Moreover, ROS-induced astrocyte death is also thought to play a role in the occurrence of HAD $[26,27]$.

Here we show that a short exposure of exogenous hydrogen peroxide to nef-expressing astrocytes led to their rapid cell death. The early detection of a high number of propidium iodide/annexin $\mathrm{V}$ double positive cells points to necrotic cell death [34], which was previously suggested when astrocytes are subjected to tertiary-butyl hydroperoxide [35]. But it can not be finally defined only from this observation what kind of cell death exactly occurred in our model. Also it depends on the concentration of hydrogen peroxide applied whether a cell dies in an apoptotic or necrotic manner [36]. In this context it is interesting to note that astrocytes are vulnerable to hydrogen peroxide at concentrations ranging from $0.5 \mathrm{mM}$ to $2.5 \mathrm{mM}$ [27], values approximately a 1.000 fold higher than the concentration applied to induce death of nef-expressing astrocytes herein. So it remains a challenge for further studies to elucidate what HIV-1 Nef
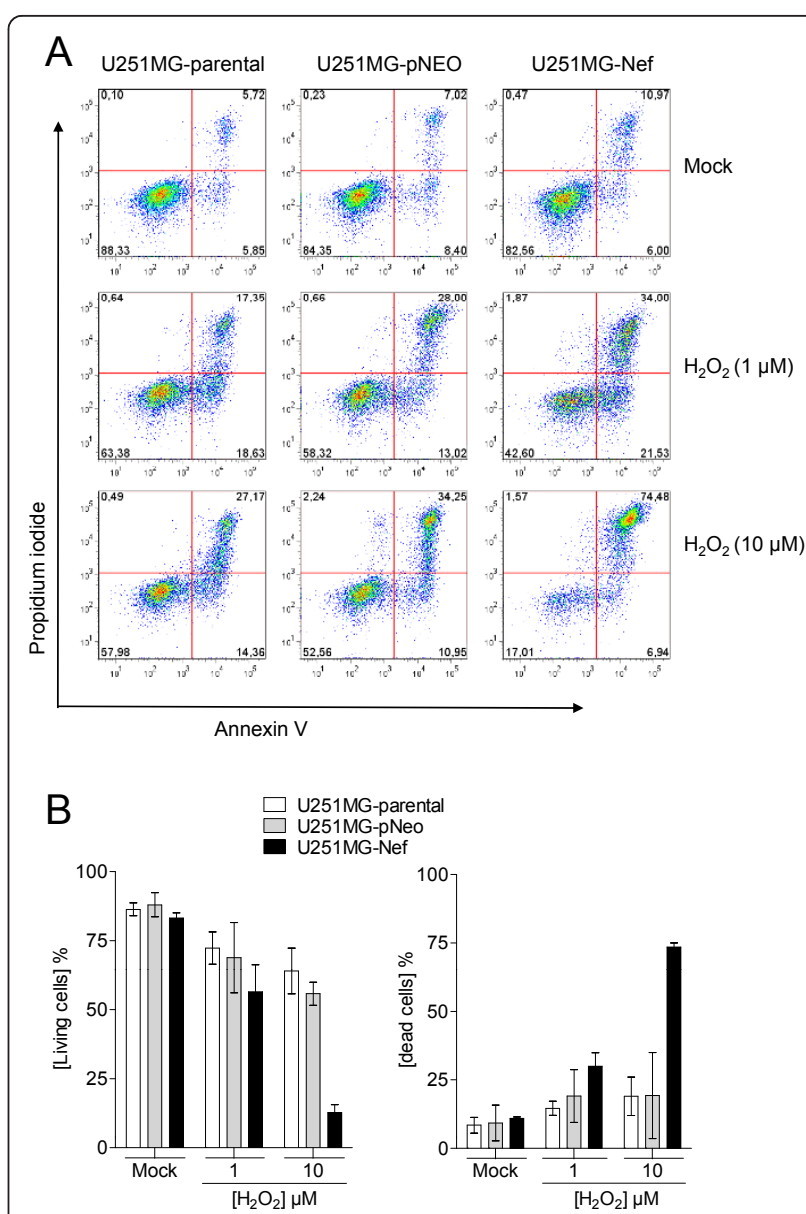

Figure 3 Hydrogen peroxide leads to rapid loss of the cell membrane integrity in nef-expressing astrocytes. (A) U251MGparental, -pNeo and -Nef cells were treated with hydrogen peroxide for $30 \mathrm{~min}$ at concentrations as indicated. Cells then were washed twice with PBS, incubated in VLE-RPMI 1640 medium containing 10\% FCS for a further $3 \mathrm{~h} 30 \mathrm{~min}$ and subsequently the annexin $\mathrm{V}$ assay was performed as described in the Methods section. (B) Summary of three independent experiments. Annexin V, PI doublenegative cells (living cells) and annexin V, PI double-positive cells (dead cells) are shown.

precisely alters in the cell leading to increased sensitivity to exogenous hydrogen peroxide. Intriguingly, it has been shown during the preparation of this manuscript that HIV-1 Nef in primary human astrocytes and in the brain of mice increases oxidative stress [37], which is in line with our finding.

Since HIV-1 Nef is known to inhibit apoptosis of T-cells $[29,38,39]$ and monocytes/macrophages $[40,41]$, it was somewhat surprising that TNF-alpha decreased the viability of U251MG-Nef cells and U251MG-parental cells equally. Additionally, this finding is in contrast to previously reported data demonstrating that HIV-1 Nef prevents TNF-alpha triggered apoptosis in astrocytic U251MG cells [42]. This discrepancy may be due to the 


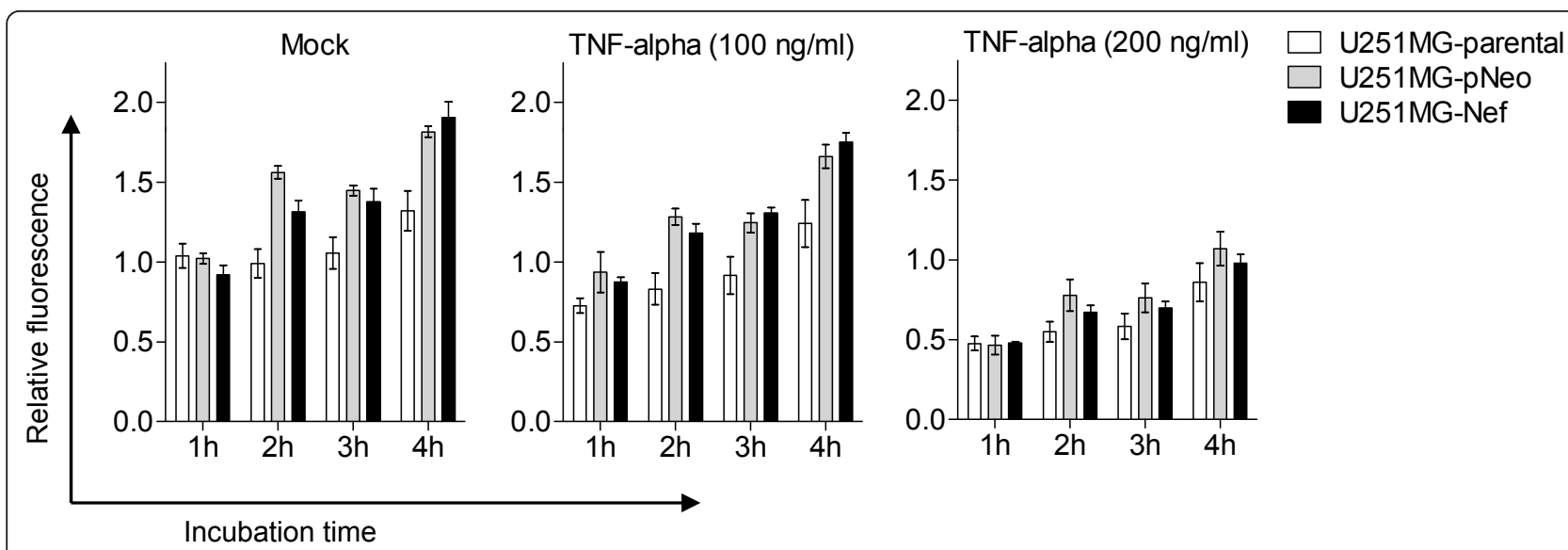

Figure 4 HIV-1 Nef does not modulate TNF-alpha decreased viability of astrocytes. U251MG-parental, -pNeo and -Nef cells were treated with TNF-alpha for $24 \mathrm{~h}$ at indicated concentrations. The medium was then exchanged and cell viability assay was performed as described in the Material section. The times indicated are relative to the moment of adding AlamarBlue ${ }^{\circledR}$ reagent to the cell culture medium. The relative fluorescence represents the ratio of the fluorescence intensity of study cells versus mock-treated cells at $1 \mathrm{~h}$ after start of the assay. Data represent mean \pm s.e.m. $(n=5)$.

use of cells stably transfected with nef in our study, which could clearly well simulate the long term effect of HIV-1 Nef in chronically infected cells [43] than cells transiently transfected with nef. Moreover, involvement of HIV-1 Nef in cell survival is subject to generally controversy $[44,45]$.

HIV-1 encodes a glutathione peroxidase [46], which has been shown to protect the cell against exogenous and endogenous ROS [47]. Consequently, what ever the reason why HIV-1 Nef causes an increase of sensitivity towards hydrogen peroxide, it is conceivable that the HIV-1 GPX could counteract this action of HIV-1 Nef by detoxifying hydrogen peroxide. Thereby HIV-1 GPX would prevent the cytotoxic potential of HIV-Nef, which is considered as a progression factor in AIDS [48-50] and known to induce an AIDS-like disease in a mouse model $[51,52]$. Thus, this could explain the paradoxical effect that functional HIV-1 GPXs are frequently found in long-term non-progressors while non-functional HIV-1 GPXs are present in HIV-1 isolates from patients developing AIDS [47].

\section{Conclusions}

Besides other known direct and indirect effects of HIV-1 proteins, HIV-1 Nef may contribute to cellular and tissue injury frequently detected in HIV-1 infected individuals, including various AIDS-associated diseases such as HAD, by increasing the sensitivity of Nef-harboring cells to hydrogen peroxide.

\section{Methods}

\section{Cell culture}

The human astrocytoma cell line U251MG was obtained from M. Brenner (National Institutes of Health, Bethesda, MD). The cell lines U251MG-Nef Bru $_{\text {clone 4/4.2 stably }}$ expressing nef from HIV-1 $1_{\text {Bru }}$ (GenBank accession number K02013) and U251MG-pNeo carrying only the neomycin resistance gene were established as reported [53]. HIV-1 Nef expression was confirmed by immunoblotting (Figure 5). Cells were routinely incubated at $37^{\circ}$ under $5 \%$ CO2, and 90\% humidity in VLE-RPMI 1640 medium certified to contain $<0.01$ endotoxin units $/ \mathrm{ml}$, and supplemented with $10 \%$ fetal calf serum (FCS), $100 \mathrm{U} / \mathrm{ml}$ penicillin as well as $100 \mu \mathrm{g} / \mathrm{ml}$ streptomycin (all from Biochrom AG, Berlin, Germany). Before treatment with hydrogen peroxide (Merck KgaA) or TNF-alpha (BioSource International Inc., Camarillo, CA), cells were seeded at a density of $1 \times 10^{5}$ cells $/ \mathrm{ml}$ in 96-well flat bottomed microtiter plates (BD Biosciences) for the cell viability assay or in 12-well plates (Costar) for the annexin $\mathrm{V}$ assay and incubated overnight in VLE-RPMI 1640 medium supplemented with $10 \%$ FCS.

\section{Immunoblotting and immunodetection}

Lysates of U251MG-parental, -pNeo and -Nef cells were prepared by directly adding 1x SDS sample loading buffer to the cells followed by sonication. Samples were separated on a 4-20\% tris-glycine gradient gel (Anamed, Darmstadt, Germany) and blotted on a nitrocellulose membrane. The blotted membranes were immunostained using mouse anti-Nef 3E6 mAb provided by K. Krohn through the National Institute for Biological Standards and Control Centralised Facility for AIDS Reagents, mouse anti-GAPDH mAb MAB347 (Chemicon International, Inc., Temecula, CA) and MFP488-conjugated goat anti-mouse antibody (MoBiTec GmbH, Göttingen, Germany), and positive signals were detected by fluorescence scanning (excitation wavelength $488 \mathrm{~nm}$, emission filter 520BP40) using the Typhoon 9410 Fluorescence 
flow cytometer (BD Biosciences). Data were evaluated using FlowJo@ software (Tree Star).

\section{Statistical analysis}

GraphPad Prism 4 (GraphPad Software, Inc., San Diego, CA) was used for statistical analysis. The Mann-Whitney test was used to compare the groups; a $P$ value of less than 0.05 was considered significant. Tests were performed exactly and two-tailed.

\section{Additional material}

Additional file 1: Hydrogen peroxide significantly decreased the viability of nef-expressing astrocytes. U251MG-parental and -Nef cells were treated with hydrogen peroxide for $30 \mathrm{~min}$ at indicated concentrations. Cells were subsequently washed twice with PBS, incubated in VLE-RPMI 1640 medium containing 10\% FCS for a further $48 \mathrm{~h}$. The medium was then exchanged and cell viability assay was performed as described in the Methods section. The relative fluorescence represents the ratio of the fluorescence intensity of study cells versus mock-treated. Data obtained after $4 \mathrm{~h}$ of starting the assay represent mean \pm s.e.m. $(n=6) ;{ }^{* *}, P<0.01$.

Additional file 2: TNF-alpha equally induces PS externalization in U251MG-parental and -Nef cells. Cells were treated with TNF-alpha for $4 \mathrm{~h}$ or with hydrogen peroxide for $30 \mathrm{~min}$ at concentrations as indicated. Cells treated with hydrogen peroxide were washed twice with PBS, incubated in VLE-RPMI 1640 medium containing 10\% FCS for a further 3 h 30 min and subsequently the annexin $\mathrm{V}$ assay was performed as described in the Methods section.

Scanner (GE Healthcare), and analyzed using ImageQuant 5.2 software (Molecular Dynamics).

\section{Cell viability assay}

The AlamarBlue ${ }^{\circledR}$ reagent (Molecular Probes, Inc., Eugene, OR) containing the water soluble, non-toxic dye resazurin (7-Hydroxy-3H-phenoxazin-3-one 10-oxide) was used to quantify mitochondrial activity according to the manufacturer's recommendation. Briefly, 1/10th of the volume of AlamarBlue ${ }^{\mathbb{R}}$ reagent was added directly to the cells in culture medium. Using the Typhoon ${ }^{\mathrm{TM}} 9410$ fluorescence scanner (GE Healthcare), fluorescence measurement was performed by applying an excitation wavelength of $532 \mathrm{~nm}$ and an emission filter of 580 BP30 nm. Data were analyzed using ImageQuant ${ }^{\mathrm{TM}} \mathrm{TL}$ software (GE Healthcare). The fluorescence intensity of medium containing only AlamarBlue ${ }^{\circledR}$ was determined simultaneously and was subtracted from all values.

\section{Annexin V assay}

Phosphatidylserine on the cell surface was detected with the Annexin V-FITC Apoptosis Detection Kit I (BD Biosciences). Briefly, cells were plated and treated in 12well plates (Costar). Then cells were washed twice with cold PBS and incubated in the dark for 15 min in $1 \times$ binding buffer supplemented with annexin V-FITC. Propidium iodide (PI) was added to the cell suspension immediately before analyzing with the BD FACSCanto ${ }^{\mathrm{TM}}$

\section{Acknowledgements} Nasim Kroegel, B.Sc., for reviewing the manuscript, and Volker Erfle for his general support. This study was supported by an internal grant from the Helmholtz Zentrum München.

\section{Author details}

${ }^{1}$ Institute of Virology, Technical University of Munich/Helmholtz Zentrum München, 81675 Munich, Germany. ${ }^{2}$ Institute for Infectious Diseases and Zoonoses, Ludwig-Maximilians-University Munich, 80539 Munich, Germany.

\section{Authors' contributions}

MHL conceived and designed the experiments, SM performed the experiments, SM and MHL analyzed the data, MHL wrote the paper. All authors have read and approved the final manuscript.

\section{Authors' information}

After receiving her M.Sc. in Molecular Biotechnology, SM moved to the Physiology Weihenstephan, Technical University Munich, Freising, Germany to work for her PhD.

MHL received his PhD in Biology from the Friedrich-Schiller-University of Jena, Germany and currently holds a faculty position at the Institute for Infectious Diseases and Zoonoses, Ludwig-Maximilians-Universität München, Germany.

\section{Competing interests}

The authors declare that they have no competing interests.

Received: 6 September 2010 Accepted: 22 January 2011

Published: 22 January 2011

\section{References}

1. Gonzalez-Scarano F, Martin-Garcia J: The neuropathogenesis of AIDS. Nat Rev Immunol 2005, 5:69-81.
The authors wish to thank Susanne Kramer for providing astrocytic cells, 
2. Kaul M, Garden GA, Lipton SA: Pathways to neuronal injury and apoptosis in HIV-associated dementia. Nature 2001, 410:988-994.

3. Minagar A, Commins D, Alexander JS, Hoque R, Chiappelli F, Singer EJ, Nikbin B, Shapshak P: NeuroAIDS: characteristics and diagnosis of the neurological complications of AIDS. Mol Diagn Ther 2008, 12:25-43.

4. Piacentini M, Kroemer G: Cell death pathways in retroviral infection. Cell Death Differ 2005, 12(1):835-836.

5. Churchill MJ, Wesselingh SL, Cowley D, Pardo CA, McArthur JC, Brew BJ, Gorry PR: Extensive astrocyte infection is prominent in human immunodeficiency virus-associated dementia. Ann Neurol 2009, 66:253-258.

6. Perea $G$, Araque A: Communication between astrocytes and neurons: a complex language. J Physiol Paris 2002, 96:199-207.

7. Chen Y, Swanson RA: Astrocytes and brain injury. I Cereb Blood Flow Metab 2003, 23:137-149.

8. Bouzier-Sore AK, Merle M, Magistretti PJ, Pellerin L: Feeding active neurons: (re)emergence of a nursing role for astrocytes. J Physiol Paris 2002, 96:273-282.

9. Epstein LG, Gendelman HE: Human immunodeficiency virus type 1 infection of the nervous system: pathogenetic mechanisms. Ann Neurol 1993, 33:429-436.

10. Sabri F, Titanji K, De Milito A, Chiodi F: Astrocyte activation and apoptosis: their roles in the neuropathology of HIV infection. Brain Pathol 2003, 13:84-94.

11. Shi B, De Girolami U, He J, Wang S, Lorenzo A, Busciglio J, Gabuzda D: Apoptosis induced by HIV-1 infection of the central nervous system. J Clin Invest 1996, 98:1979-1990.

12. Petito CK, Roberts B: Evidence of apoptotic cell death in HIV encephalitis. Am J Pathol 1995, 146:1121-1130.

13. Bagasra O, Lavi E, Bobroski L, Khalili K, Pestaner JP, Tawadros R, Pomerantz RJ: Cellular reservoirs of HIV-1 in the central nervous system of infected individuals: identification by the combination of in situ polymerase chain reaction and immunohistochemistry. AIDS 1996, 10:573-585.

14. Tornatore C, Chandra R, Berger JR, Major EO: HIV-1 infection of subcortical astrocytes in the pediatric central nervous system. Neurology 1994, 44:481-487.

15. Saito Y, Sharer LR, Epstein LG, Michaels J, Mintz M, Louder M, Golding K, Cvetkovich TA, Blumberg BM: Overexpression of nef as a marker for restricted HIV-1 infection of astrocytes in postmortem pediatric central nervous tissues. Neurology 1994, 44:474-481.

16. Mordelet E, Kissa K, Cressant A, Gray F, Ozden S, Vidal C, Charneau P, Granon S: Histopathological and cognitive defects induced by Nef in the brain. FASEB J 2004, 18:1851-1861.

17. Ranki A, Nyberg M, Ovod V, Haltia M, Elovaara I, Raininko R, Haapasalo H, Krohn K: Abundant expression of HIV Nef and Rev proteins in brain astrocytes in vivo is associated with dementia. AIDS 1995, 9:1001-1008

18. Lehmann MH, Masanetz S, Kramer S, Erfle V: HIV-1 Nef upregulates CCL2/ MCP-1 expression in astrocytes in a myristoylation- and calmodulindependent manner. J Cell Sci 2006, 119:4520-4530.

19. Conant K, Garzino-Demo A, Nath A, MCArthur JC, Halliday W, Power C Gallo RC, Major EO: Induction of monocyte chemoattractant protein-1 in HIV-1 Tat-stimulated astrocytes and elevation in AIDS dementia. Proc Natl Acad Sci USA 1998, 95:3117-3121.

20. Cinque P, Vago L, Mengozzi M, Torri V, Ceresa D, Vicenzi E, Transidico P, Vagani A, Sozzani S, Mantovani A, et al: Elevated cerebrospinal fluid levels of monocyte chemotactic protein-1 correlate with HIV-1 encephalitis and local viral replication. AIDS 1998, 12:1327-1332.

21. Eugenin EA, Osiecki K, Lopez L, Goldstein H, Calderon TM, Berman JW: CCL2/monocyte chemoattractant protein-1 mediates enhanced transmigration of human immunodeficiency virus (HIV)-infected leukocytes across the blood-brain barrier: a potential mechanism of HIVCNS invasion and NeuroAIDS. J Neurosci 2006, 26:1098-1106.

22. Gonzalez E, Rovin BH, Sen L, Cooke G, Dhanda R, Mummidi S, Kulkarni H, Bamshad MJ, Telles V, Anderson SA, et al: HIV-1 infection and AIDS dementia are influenced by a mutant MCP-1 allele linked to increased monocyte infiltration of tissues and MCP-1 levels. Proc Natl Acad Sci USA 2002, 99:13795-13800

23. Brabers NA, Nottet HS: Role of the pro-inflammatory cytokines TNF-alpha and IL-1beta in HIV-associated dementia. Eur J Clin Invest 2006, 36:447-458.
24. Williams KC, Hickey WF: Central nervous system damage, monocytes and macrophages, and neurological disorders in AIDS. Annu Rev Neurosci 2002, 25:537-562.

25. Desagher S, Glowinski J, Premont J: Astrocytes protect neurons from hydrogen peroxide toxicity. J Neurosci 1996, 16:2553-2562.

26. Robb SJ, Connor JR: An in vitro model for analysis of oxidative death in primary mouse astrocytes. Brain Res 1998, 788:125-132.

27. Feeney CJ, Frantseva MV, Carlen PL, Pennefather PS, Shulyakova N, Shniffer C, Mills LR: Vulnerability of glial cells to hydrogen peroxide in cultured hippocampal slices. Brain Res 2008, 1198:1-15.

28. Kroemer G, El-Deiry WS, Golstein P, Peter ME, Vaux D, Vandenabeele $P$, Zhivotovsky B, Blagosklonny MV, Malorni W, Knight RA, et al: Classification of cell death: recommendations of the Nomenclature Committee on Cell Death. Cell Death Differ 2005, 12(2):1463-1467.

29. Geleziunas R, Xu W, Takeda K, Ichijo H, Greene WC: HIV-1 Nef inhibits ASK1-dependent death signalling providing a potential mechanism for protecting the infected host cell. Nature 2001, 410:834-838.

30. Baruchel S, Wainberg MA: The role of oxidative stress in disease progression in individuals infected by the human immunodeficiency virus. J Leukoc Biol 1992, 52:111-114.

31. Pace GW, Leaf CD: The role of oxidative stress in HIV disease. Free Radic Biol Med 1995, 19:523-528.

32. Gray F, Adle-Biassette H, Chretien F, Lorin de la Grandmaison G, Force G, Keohane $C$ : Neuropathology and neurodegeneration in human immunodeficiency virus infection. Pathogenesis of HIV-induced lesions of the brain, correlations with HIV-associated disorders and modifications according to treatments. Clin Neuropathol 2001, 20:146-155.

33. Mollace V, Nottet HS, Clayette P, Turco MC, Muscoli C, Salvemini D, Perno CF: Oxidative stress and neuroAIDS: triggers, modulators and novel antioxidants. Trends Neurosci 2001, 24:411-416.

34. Vermes I, Haanen C, Steffens-Nakken H, Reutelingsperger C: A novel assay for apoptosis. Flow cytometric detection of phosphatidylserine expression on early apoptotic cells using fluorescein labelled Annexin V. J Immunol Methods 1995, 184:39-51.

35. Robb SJ, Connor JR: Nitric oxide protects astrocytes from oxidative stress. Ann N Y Acad Sci 2002, 962:93-102.

36. Hampton $M B$, Orrenius $S$ : Dual regulation of caspase activity by hydrogen peroxide: implications for apoptosis. FEBS Lett 1997, 414:552-556.

37. Acheampong EA, Roschel C, Mukhtar M, Srinivasan A, Rafi M, Pomerantz RJ, Parveen Z: Combined effects of hyperglycemic conditions and HIV-1 Nef: a potential model for induced HIV neuropathogenesis. Virol J 2009, 6:183.

38. Wolf D, Witte V, Laffert B, Blume K, Stromer E, Trapp S, d'Aloja P, Schurmann A, Baur AS: HIV-1 Nef associated PAK and PI3-kinases stimulate Akt-independent Bad-phosphorylation to induce antiapoptotic signals. Nat Med 2001, 7:1217-1224.

39. Greenway AL, McPhee DA, Allen K, Johnstone R, Holloway G, Mills J, Azad A, Sankovich S, Lambert P: Human immunodeficiency virus type 1 Nef binds to tumor suppressor p53 and protects cells against p53mediated apoptosis. J Virol 2002, 76:2692-2702.

40. Choi HJ, Smithgall TE: HIV-1 Nef promotes survival of TF-1 macrophages by inducing $\mathrm{BCl}-\mathrm{XL}$ expression in an extracellular signal-regulated kinasedependent manner. J Biol Chem 2004, 279:51688-51696.

41. Olivetta E, Federico M: HIV-1 Nef protects human-monocyte-derived macrophages from HIV-1-induced apoptosis. Exp Cell Res 2006, 312:890-900

42. Robichaud GA, Poulin L: HIV type 1 nef gene inhibits tumor necrosis factor alpha-induced apoptosis and promotes cell proliferation through the action of MAPK and JNK in human glial cells. AIDS Res Hum Retroviruses 2000, 16:1959-1965.

43. Kramer-Hammerle S, Hahn A, Brack-Werner R, Werner T: Elucidating effects of long-term expression of HIV-1 Nef on astrocytes by microarray, promoter, and literature analyses. Gene 2005, 358:31-38.

44. Schindler M, Munch J, Kirchhoff F: Human immunodeficiency virus type 1 inhibits DNA damage-triggered apoptosis by a Nef-independent mechanism. J Virol 2005, 79:5489-5498.

45. Laforge M, Petit F, Estaquier J, Senik A: Commitment to apoptosis in CD4 $(+)$ T lymphocytes productively infected with human immunodeficiency virus type 1 is initiated by lysosomal membrane permeabilization, itself induced by the isolated expression of the viral protein Nef. J Virol 2007, 81:11426-11440. 
46. Zhao L, Cox AG, Ruzicka JA, Bhat AA, Zhang W, Taylor EW: Molecular modeling and in vitro activity of an HIV-1-encoded glutathione peroxidase. Proc Natl Acad Sci USA 2000, 97:6356-6361.

47. Cohen I, Boya P, Zhao L, Metivier D, Andreau K, Perfettini JL, Weaver JG, Badley A, Taylor EW, Kroemer G: Anti-apoptotic activity of the glutathione peroxidase homologue encoded by HIV-1. Apoptosis 2004, 9:181-192.

48. Dyer WB, Geczy AF, Kent SJ, Mclntyre LB, Blasdall SA, Learmont JC, Sullivan JS: Lymphoproliferative immune function in the Sydney Blood Bank Cohort, infected with natural nef/long terminal repeat mutants, and in other long-term survivors of transfusion-acquired HIV-1 infection. AIDS 1997, 11:1565-1574.

49. Hofmann-Lehmann R, Vlasak J, Williams AL, Chenine AL, McClure HM, Anderson DC, O'Neil S, Ruprecht RM: Live attenuated, nef-deleted SIV is pathogenic in most adult macaques after prolonged observation. AIDS 2003, 17:157-166.

50. Kestler HW, Ringler DJ, Mori K, Panicali DL, Sehgal PK, Daniel MD, Desrosiers RC: Importance of the nef gene for maintenance of high virus loads and for development of AIDS. Cell 1991, 65:651-662.

51. Simard MC, Chrobak P, Kay DG, Hanna Z, Jothy S, Jolicoeur P: Expression of simian immunodeficiency virus nef in immune cells of transgenic mice leads to a severe AIDS-like disease. J Virol 2002, 76:3981-3995.

52. Hanna Z, Kay DG, Rebai N, Guimond A, Jothy S, Jolicoeur P: Nef harbors a major determinant of pathogenicity for an AIDS-like disease induced by HIV-1 in transgenic mice. Cell 1998, 95:163-175.

53. Kohleisen B, Shumay E, Sutter G, Foerster R, Brack-Werner R, Nuesse M, Erfle V: Stable expression of HIV-1 Nef induces changes in growth properties and activation state of human astrocytes. AIDS 1999, 13:2331-2341.

doi:10.1186/1743-422X-8-35

Cite this article as: Masanetz and Lehmann: HIV-1 Nef increases astrocyte sensitivity towards exogenous hydrogen peroxide. Virology Journal 2011 8:35.

\section{Submit your next manuscript to BioMed Central and take full advantage of:}

- Convenient online submission

- Thorough peer review

- No space constraints or color figure charges

- Immediate publication on acceptance

- Inclusion in PubMed, CAS, Scopus and Google Scholar

- Research which is freely available for redistribution

Submit your manuscript at www.biomedcentral.com/submit
Biomed Central 